\title{
低温鉛フリーはんだ接合を目的としたスズー亜鉛共晶合金の 電析および重鉛の共析機構
}

\author{
縄舟 秀美*, 中谷 敏雄 ${ }^{* *}$, 赤松 謙祐 ${ }^{*}$, 内田 衛***, 小幡 恵吾****
}

\author{
Electrodeposition of Tin-Zinc Eutectics Alloy and Codeposition Mechanism of Zinc \\ for Low Temperature Lead-Free Soldering
}

Hidemi NAWAFUNE*, Toshio NAKATANI**, Kensuke AKAMATSU*, Ei UCHIDA ${ }^{* * *}$ and Keigo OBATA****

\footnotetext{
*'甲南大学理工学部, 甲南大学ハイテク・リサーチ・センター（テ658-8501 兵庫県神戸市東灘区岡本 8-9-1）

**甲南大学大学院自然科学研究科 (テ658-8501 兵庫県神戸市東灘区岡本 8-9-1)

***石原薬品株式会社（广652-0806 兵庫県神戸市兵庫区西柳原町 5-26）

****株式会社大和化成研究所（广674-0093 兵庫県明石市二見町南二見 21-8）

* Faculty of Science and Engineering, High Tech. Research Center, Konan University (8-9-1 Okamoto, Higashinada-ku, Kobe-shi, Hyogo 658-8501)

** Graduate School of Science, Konan University (8-9-1 Okamoto, Higashinada-ku, Kobe-shi, Hyogo 658-8501)

*** Ishihara Chemical Co., Ltd. (5-26 Nishiyanagihara-cho, Hyogo-ku, Kobe-shi, Hyogo 652-0806)

****Daiwa Fine Chemicals Co., Ltd. (21-8 Minamifutami, Futami-cho, Akashi-shi, Hyogo 674-0093)
}

\begin{abstract}
概要 スズー亜鈆共晶合金は，融点が現行のスズー鉛共晶合金のそれに近いことから，鉛フリーはんだの候補として期待さ れている。ポリオキシエチレンー $\alpha$ ナフトール (POEN)を添加剤とするスルホコ八ク酸浴から, カソード電流密度 $0.5 \sim 3 \mathrm{~A} / \mathrm{dm}^{2}$ に扔いて，共晶組成（亜鉛 9 mass \%) を有する合金皮膜が得られた。POENの添加は，スズ析出の分極を増大し，低電流密度 領域におけるスズの優先析出を抑制することにより, 亜鉛の共析を可能にした。めっき浴は極めて安定であり，6力月経過後 においても $\mathrm{Sn}^{4+}$ 化合物の沈殿形成は認められなかった。スズー亜鉛共晶合金皮膜は， $\beta$-スズ相と亜鉛相からなり，その融点は $198^{\circ} \mathrm{C}$ であった。銅素地上のスズ-亜鉛共晶合金皮膜には，1年間の室温経時後においてあウイスカの発生は認められなかった。
\end{abstract}

\begin{abstract}
Electrodeposited tin-zinc eutectic alloy is a promising candidate to replace tin-lead solder coatings and provide low temperature soldering. The eutectic alloy film (Sn-9.0Zn, mass $\%$ ) of the desired constituent was deposited at cathode current density $0.5-3 \mathrm{~A} / \mathrm{dm}^{2}$ in a sulfosuccinate bath using the additive polyoxyethylene- $\alpha$-naphthol (POEN). The presence of POEN increased tin deposition polarization, markedly inhibited preferencial deposition of tin over a noble potential range, and an appreciable amount of zinc was codeposition. The bath is stable systems, precipitate consisting of metastannic acid were not observed after standing for six months. The eutectic alloy film consists of $\beta$-tin and zinc phases, and its solidus temperature was $198^{\circ} \mathrm{C}$. Whisker were not observed on the eutectic alloy film on the copper substrate after one year of aging at room temperature.
\end{abstract}

Key Words: Lead-Free Solder Plating, Low-Temperature Soldering, Sn-Zn Eutectic Alloy Film, Bath Stability, Whisker-Free

\section{1. 緒 言}

はんだ接合における鉛フリー化は，電子産業および自動 車産業において緊急・重要課題である。1998年度，新エネ ルギー・産業技術総合開発機構 (NEDO)の「鉛フリーはん だ規格化のための研究開発」プロジェクトにおいて，鉛フ リーはんだの標準化のための客観的デー夕収集，情報公開 を目的として $\mathrm{Sn}-\mathrm{Ag}-\mathrm{Cu}$ 系, $\mathrm{Sn}-\mathrm{Bi}-\mathrm{Ag}$ 系および $\mathrm{Sn}-\mathrm{Cu}$ 系は んだを中心に特性評価がなされた1)。

電化製品の鉛フリー化において，電子部品の実装におけ る接合信頼性の確保が重要であることから，鉛フリーはん だの開発に加え，電子部品電極部の表面処理がキーテクノ ロジーとなる。現在までに，電子部品のはんだ接合を目的 とした, $\mathrm{Sn}-\mathrm{Bi}$ 合金 ${ }^{2), 3)}, \mathrm{Sn}-\mathrm{Ag}$ 共晶合金 ${ }^{4)-7)}$ および $\mathrm{Sn}-\mathrm{Cu}$ 共晶合金 ${ }^{8), 9)}$ 等の鉛フリーはんだめっきに関する研究が行わ れてきた。しかし，現段階では統一された基本概念の下に，
鉊フリーはんだ接合に対応するめうき技術が採用されるに 至っていない。この理由として，現在までに主に検討され てきた鉛フリーはんだは，上述の $\mathrm{Sn}-\mathrm{Ag}-\mathrm{Cu}$ 系, $\mathrm{Sn}-\mathrm{Bi}-\mathrm{Ag}$ 系および $\mathrm{Sn}-\mathrm{Cu}$ 系はんだであり，これに対応する鉛フリー はんだめっきとして，合金成分を同じくする $\mathrm{Sn}-\mathrm{Ag}, \mathrm{Sn}-\mathrm{Cu}$ および $\mathrm{Sn}-\mathrm{Bi}$ 合金めっきが当面の対象とされてきた。しか し，これらの鉛フリーはんだめっきには，それぞれ，材料 コスト，銅素地上でのウイスカ発生および接合信頼性に問 題がある。さらに，これらの問題点に加え共通してめっき 浴の安定性および作業性に問題があることが，選定の判断 基準を不確定にしている要因の 1 つしして考えられる。めっ き浴の安定性に関しては，基本的に合金元素の標準電極電 位が関与している。上述の $\mathrm{Sn}$ 基合金めっきでは, いずれも スズに比べ標準電極電位が貴な合金成分が使用されている。 例えば, $\mathrm{Sn}-\mathrm{Cu}$ 合金の電析では, $\mathrm{Sn}$ の標準電極電位 $\left(\mathrm{Sn}^{2+}+\right.$ $\left.2 \mathrm{e}^{-} \rightarrow \mathrm{Sn}, \mathrm{E}^{0}=-0.138 \mathrm{~V}\right)$ に比へ， $\mathrm{Cu}$ の標準電極電位 $\left(\mathrm{Cu}^{2+}+\right.$ 
$\left.2 \mathrm{e}^{-} \rightarrow \mathrm{Cu}, \mathrm{E}^{0}=0.337 \mathrm{~V}\right)$ は極めて貴である。浴中において， $\mathrm{Sn}^{2+}$ イオンは $\mathrm{Cu}^{2+}$ イオンを $\mathrm{Cu}^{+}$イオンに還元し, 自身 $\mathrm{Sn}^{4+}$ イオンに酸化することにより, 浴中にメタスズ(IV)酸の沈 殿を形成する。このような現象は, $\mathrm{Ag}^{+}$または $\mathrm{Bi}^{3+}$ イオン が浴中に存在する場合においても同様であり,これらの現 象を抑制することは難しい。

2000 年度, エレクトロニクス実装学会 (JIEP)において, 低温鉛フリーはんだ実装技術開発プロジェクトが実施され ている(10)。エネルギ消費の抑制および複合材料である電子 部品の耐熱性の観点からも，低温鉛フリーはんだ実装は望 ましい。この目的に適合するはんだ材料としては, Sn-Zn 系はんだが有力な候補であり，材料コストが安価であり， イオンマイグレーションの発生においても問題はない11)。 また，この材料の久点であった耐酸化性に関しても，優れ たはんだフラックスおよびペーストが開発されるようにな り，その実施例が報告されるようになってきた ${ }^{12), 13)}$ 。 $\mathrm{Sn}-\mathrm{Zn}$ 合金の電析においては, $Z n$ の標準電極電位 $\left(Z^{2+}+2 \mathrm{e}^{+} \rightarrow \mathrm{Zn}\right.$, $\left.\mathrm{E}^{0}=-0.763 \mathrm{~V}\right)$ が $\mathrm{Sn}$ のそれに比べ卑であることから, 上述の $\mathrm{Sn}-\mathrm{Ag}, \mathrm{Sn}-\mathrm{Cu}$ および $\mathrm{Sn}-\mathrm{Bi}$ 合金の電析に共通の欠点であ る, 共存金属イオンのレドックス系からも浴の安定性に問 題がない。

筆者らは，すでにポリオキシエチレンノニルフェノール エーテル $(\mathrm{POENPE})$ を添加剤とするスルホコハク酸浴から の Sn-Zn 共晶合金の電析について報告した ${ }^{14)}$ 。しかし，添 加剂として使用したPOENPEは, 骨格構造に内分泌かく乱 物質（環境ホルモン）に指定されているノニルフェノール 構造を有することから，その使用に問題が生じてきた ${ }^{15)} 。$ 本研究では, 低温はんだ接合が可能であり，材料コストに おいても問題がない $\mathrm{Sn}-Z \mathrm{n}$ 系はんだ接合に対応する $\mathrm{Sn}-\mathrm{Zn}$ 合金めっきについて，内分泌かく乱物質としての作用のな い添加剂を用いた，スルホコハク酸浴から Sn-9Zn (mass\%) 共晶合金皮膜を得るためのめっき条件を確立するとともに, 浴の安定性および $\mathrm{Zn}$ の共析機構を電気化学的に検討した。 また, 析出皮膜の結晶構造, 融解特性およびウイスカの発 生の有無についても検討した。

\section{2. 実験方法}

\section{1 基本めっき浴および析出皮膜の組成}

基本浴の組成およびめっき条件を Table 1 に示す。浴中 の $\mathrm{Sn}^{2+}+\mathrm{Zn}^{2+}$ イオン濃度は $0.2 \mathrm{~mol} / \mathrm{L}$ であり, $\mathrm{Sn}^{2+}$ および $\mathrm{Zn}^{2+}$ イオンのモル濃度比 $\mathrm{Zn}^{2+} /\left(\mathrm{Sn}^{2+}+\mathrm{Zn}^{2+}\right)$ は, 目的の $\mathrm{Sn}-9$ mass $\% Z n$ 共晶合金の組成比になるように調製した。添加 剂には非イオン界面活性剤であるポリオキシエチレン $-\alpha-$ ナフトール（エチレンオキサイド付加モル数 $=10$, 以下 POEN と略）を使用し，その作用機構を検討した。POEN の添加は分極を増大し，めっき浴中の標準電極電位の貴な 合金成分の優先析出を抑制する ${ }^{6,7)}$ 。皮膜特性の測定用途 に応じて，素地として Pt板， $\mathrm{Cu}$ 板， $\mathrm{Ni}$ めっき（膜厚 $1 \mu \mathrm{m}$ ）
Table 1. Basic bath composition and plating condition of Sn-Zn alloy plating

\begin{tabular}{|c|c|}
\hline $\mathrm{Sn}\left(\mathrm{OSO}_{2} \mathrm{NH}_{2}\right)_{2}$ & $0.193 \mathrm{~mol} / \mathrm{L}$ \\
\hline $\mathrm{ZnSO}_{4}$ & $0.007 \mathrm{~mol} / \mathrm{L}$ \\
\hline Total metal ion & $\left(\mathrm{Sn}^{2+}+\mathrm{Zn}^{2+} 0.20 \mathrm{~mol} / \mathrm{L}\right)$ \\
\hline Sulfosuccinic acid & $1.0 \mathrm{~mol} / \mathrm{L}$ \\
\hline POEN & $0.5 \mathrm{~g} / \mathrm{L}$ \\
\hline $\mathrm{pH}$ & 4.5 \\
\hline Bath temperature & $25^{\circ} \mathrm{C}$ \\
\hline Current density & $0.5-3.0 \mathrm{~A} / \mathrm{dm}^{2}$ \\
\hline \multicolumn{2}{|c|}{ Additive } \\
\hline & $\left.\mathrm{H}_{2} \mathrm{O}\right)_{10} \mathrm{H}$ \\
\hline \multicolumn{2}{|c|}{$\begin{array}{r}\text { Polyoxyethylene- } \alpha \text {-naphthol } \\
\text { (POEN) }\end{array}$} \\
\hline
\end{tabular}

$\mathrm{Cu}$ 板およびステンレス鋼 (SUS304) 板 $\left(25 \times 25 \times 0.3^{\mathrm{t}} \mathrm{mm}\right)$ を使 用した。スターラかく拌下において通電量 $80 \mathrm{C}$ の定電流電 解を行い，合金皮膜を作製した。アノードにはSn電極を 使用した。析出皮膜は濃塩酸に溶解後, セイコー電子工業 製 ICP 発光分光分析装置 SPS 7700 により $\mathrm{Sn}^{2+}$ および $\mathrm{Zn}^{2+}$ イオン濃度を定量し, 皮膜組成および電流効率を算出し た。

\section{2 カソード分極曲線およびカソード近傍の $\mathrm{pH}$ 測定}

定電位電解法による部分カソード分極の測定には, 北斗 電工製電気化学システム HZ-3000を使用した。作用極には, 直径 $2 \mathrm{~mm}$, 長さ $15 \mathrm{~mm}$ の Pt 円柱電極に測定のつど厚さ $5 \mu \mathrm{m}$ の Cuめっきを施したものを使用した。対極にはPt線，参 照電極には $\mathrm{Ag} / \mathrm{AgCl}$ 電極 $(3.3 \mathrm{~mol} / \mathrm{L} \mathrm{KCl})$ を使用した。本論 文中における電極電位の值はこの参照電極を基準とした 值である。分極測定に際し, 試料溶液にあらかじめ $15 \mathrm{~min}$ 窒素通気し，溶存酸素を除去した。

所定電位において所定電気量の電解により析出した皮膜

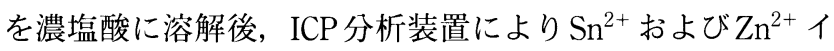
オン濃度を定量した。電解に要した電気量 $\mathrm{q}$, 電解時間 $\mathrm{t}$, 作用極表面積 $\mathrm{A}$ および析出した合金の ICPによる分析結果 から求めた各成分の電気量 $\mathrm{qSn}, \mathrm{qZn}$ から, 全電流 $\left[\mathrm{i}_{\mathrm{net}}=\right.$ $\mathrm{q} /(\mathrm{A} \times \mathrm{t})]$, 各合金成分の析出電流 $\left[\mathrm{i}_{\mathrm{Sn}}=\mathrm{q}_{\mathrm{Sn}_{\mathrm{n}}} /(\mathrm{A} \times \mathrm{t}), \mathrm{i}_{\mathrm{Zn}}=\right.$ $\left.\mathrm{q}_{\mathrm{Zn}} /(\mathrm{A} \times \mathrm{t})\right]$, 副反応に消費された電流 $\left[\mathrm{i}_{\mathrm{sub}}=\mathrm{i}_{\mathrm{net}}-\mathrm{i}_{\mathrm{Sn}}-\mathrm{i}_{\mathrm{Zn}}\right]$ を算 出することにより部分カソード分極曲線を作成した。

電解に伴う作用極（直径 $2 \mathrm{~mm}$ の Pt円板電極）近傍の $\mathrm{pH}$ は，作用極に対して垂直方向に微動可能なマイクロメータ に取りつけた微小 $\mathrm{Sb}$ 電極の $\mathrm{Ag} / \mathrm{AgCl}$ 電極に対する電位を 測定し，あらかじめ種々の $\mathrm{pH}$ の基本浴について作成した 検量線から求めた。

\section{3 析出皮膜の表面形態，結晶構造および融解特性}

Table 1 に示した基本めっき浴から析出した共晶組成を有 する合金皮膜について以下の特性を測定した。

析出皮膜の表面形態は, 日本電子製走査型電子顕微鏡 (SEM) JSM-5200により観察した。また，Cu素材上に析出し た皮膜を室温放置後, ウイスカの発生の有無をSEMにより 
観察した。合金皮膜の結晶構造は，理学電機製ガイガーフ レックス RAD II c(Cu- $\mathrm{K} \alpha)$ を用い，X線回折法により調べ た。また, $\mathrm{Cu}$ 素地上の合金皮膜の深さ方向の元素分布は, 堀場製作所製グロー放電発光表面分析装置 JY5000RF (GDOES)により测定した。

ステンレス鋼板上に析出した合金皮膜を素地から機械的 にはく離し, その融解特性を理学電機製示差走査熱量計 DSC 8270 により昇温速度 $2 \mathrm{~K} / \mathrm{min}$ で測定した。また， Cu素 地および $\mathrm{Ni}$ めっ $\mathrm{Cu}$ 板に析出した合金皮膜は, 素地とと もにパンチで打ち抜いたものを試料として同様に融解特性 を測定し，融解特性に及ぼす素地の影響を調べた。

\section{3. 結果亡考察}

\section{1 合金皮膜の組成および析出皮膜の表面形態に及ぼ} す添加剂およびpHの影響

析出皮膜の $\mathrm{Zn}$ 含有量の電流密度依存性に及ぼす添加剂 および pHの影響を Fig. 1 およびFig. 2 に示す。標準電極電 位からも予想されるように, 添加剂無添加浴 $(\mathrm{pH} 4.5)$ から はZnの共析は認められなかった。しかし，POENの添加に 伴い析出皮膜の Zn 含有量が増大し, POEN $0.5 \mathrm{~g} / \mathrm{L}$ 添加浴 からは0.5 3.0 A/ $\mathrm{dm}^{2}$ のカソード電流密度領域において, 合

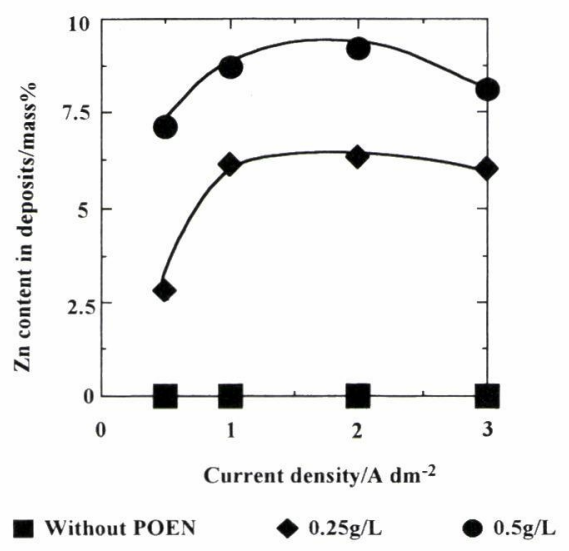

Fig. 1 Effect of addition of POEN on $\mathrm{Zn}$ content in films deposited from sulfosuccinate bath $(\mathrm{pH}$ 4.5) and its current density dependency

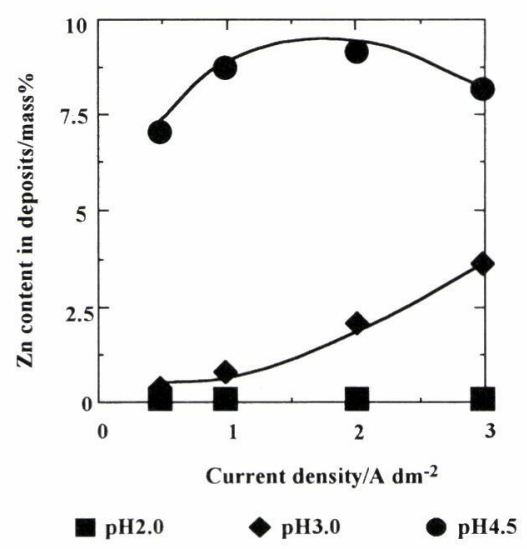

Fig. 2 Effect of $\mathrm{pH}$ on $\mathrm{Zn}$ content in films deposited from sulfosuccinate bath with $0.5 \mathrm{~g} / \mathrm{L}$ POEN and its current density dependency
金組成の電流密度依存性が小さく，共晶組成に近い $\mathrm{Sn}-\mathrm{Zn}$ 合金皮膜が析出した(Fig. 1)。 pHの影響について検討した 結果(Fig. 2), POEN $0.5 \mathrm{~g} / \mathrm{L}$ 添加浴においても， pH が低い場 合にはZnの共析はまったく認められなかった。 $\mathrm{pH}$ の上昇 およびカソード電流密度の增大に伴い, $\mathrm{Zn}$ 共析が認められ るようになり, $\mathrm{pH} 4.5, \operatorname{POEN~} 0.5 \mathrm{~g} / \mathrm{L}$ の条件下において，合 金組成の電流密度依存性が小さく, 共晶組成に近い $\mathrm{Sn}-\mathrm{Zn}$ 合金皮膜が析出した。この電流密度領域における合金析出 のカソード電流効率は約 $50 \%$ と低い值を示した。添加剤と して使用したPOEN は非イオン界面活性剤であり, $\mathrm{pH}$, 温 度および共存する塩類により是点が異なる。Table 1 に示し た基本浴組成から $\mathrm{pH}$ および POEN 濃度を变化させた場合, 曇点現象が認められた。本浴は $\mathrm{Sn}-\mathrm{Ag}, \mathrm{Sn}-\mathrm{Bi}$ および $\mathrm{Sn}-\mathrm{Cu}$ 合金めっき浴に認められた, 経時に伴う $\mathrm{Sn}^{4+}$ 化合物の沈殿 形成は皆無であり，6力月放置後においても浴は無色透明 であった。本浴は極めて安定であり，アノードや析出皮膜 上への Znの置換析出も当然生じることなく, 優れた作業 性を有している。

$\mathrm{Cu}$ 素地上にカソード電流密度 $2 \mathrm{~A} / \mathrm{dm}^{2}$ において析出した, 厚さ $5 \mu \mathrm{m}$ の電析皮膜の表面形態に及ぼすPOEN の影響を Fig. 3 に示す。POEN 無添加浴からは，粒子が粗く平滑性に 欠けた密着性の悪い皮膜が析出した。一方, POEN添加浴 からは，平滑で緻密な密着性の優れた共晶組成を有する皮 膜が析出した。

Table 1 に示した基本浴に水酸化ナトリウム水溶液を加 え, $\mathrm{pH} 5 \sim 11$ に調整後, 3 日間放置後の溶液に溶存する $\mathrm{Sn}^{2+}$ および $\mathrm{Zn}^{2+}$ イオン濃度と放置後の $\mathrm{pH}$ の関係を Fig. 4 に示す。水酸化ナトリウム水溶液添加時には，一部塩基性 塩が生成しこれが水酸化物に変化するため, 放置に伴い $\mathrm{pH}$ が若干低下した。溶液中に溶存する $\mathrm{Sn}^{2+}$ および $\mathrm{Zn}^{2+}$ イオ ン濃度は, pH9 付近において $0.1 \mathrm{mg} / \mathrm{L}$ 以下となったことか
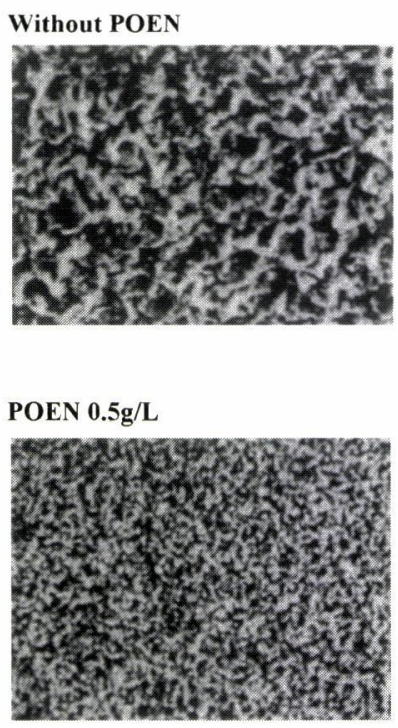

$\overline{10 \mu \mathrm{m}}$

Fig. 3 Effect of addition of POEN on surface morphology of $\mathrm{Sn}-\mathrm{Zn}$ eutectic alloy film 


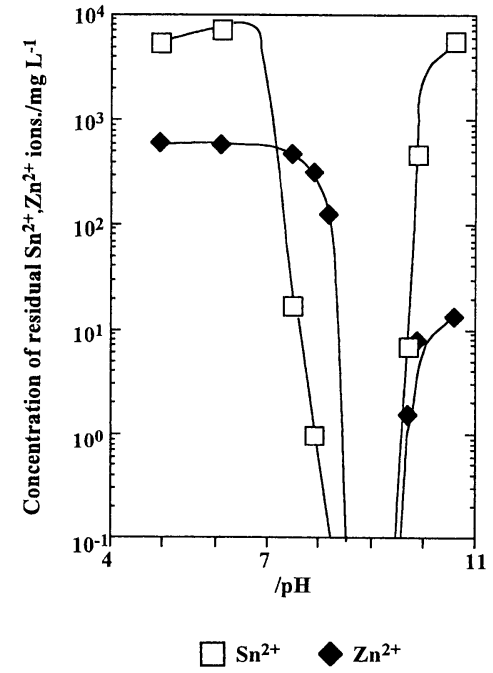

Fig. 4 Relation between $\mathrm{pH}$ and concentration of residual $\mathrm{Sn}^{2+}$ and $\mathrm{Zn}^{2+}$ ions with neutralizing sedimentation treatment

ら，本浴および本浴の水洗排水は中和沈降処理による排水 処理が可能である。

\section{$3.2 \mathrm{Zn}$ の共析機構}

添加剂無添加浴 $(\mathrm{pH} 4.5)$ および POEN 添加浴 $(\mathrm{pH}$ 4.5) の部 分カソード分極を Fig. 5 に示す。添加剂無添加浴における 析出電位は $-200 \mathrm{mV}$ 付近にあり, 貴な電位から大きな力 ソード電流が流れる。全電流 $\mathrm{i}_{\text {net }}$ に対する $\mathrm{Sn}$ 析出の部分電 流 $\mathrm{i}_{\mathrm{Sn}}$ および副反応の部分電流 $\mathrm{i}_{\text {sub }}=\left(\mathrm{i}_{\text {net }}-\mathrm{i}_{\mathrm{Sn}}-\mathrm{i}_{\mathrm{Zn}}\right)$ の占める割 合は大きく, Zn 析出の部分電流 $\mathrm{i}_{Z n}$ は極めて小さい。また, 広い電位領域において金属析出のカソード電流効率が低い ことから， $\mathrm{i}_{\mathrm{sub}}$ は水素発生に起因するものと考えられ，電 極近傍における $\mathrm{pH}$ 上昇が予想される。一方, POEN 0.5 g/L の添加に伴い, 析出電位は卑な電位 $(-500 \mathrm{mV}$ 付近) にシ フトするとともに， $\mathrm{i}_{\mathrm{Sn}}$ の抑制および $\mathrm{i}_{\mathrm{Zn}}$ の増大が認められ た。

POEN $0.5 \mathrm{~g} / \mathrm{L}$ 添加浴の部分カソード分極曲線に及ぼす $\mathrm{pH}$ の影響を Fig. 6 に示す。pH 2.0 において析出電位は -200

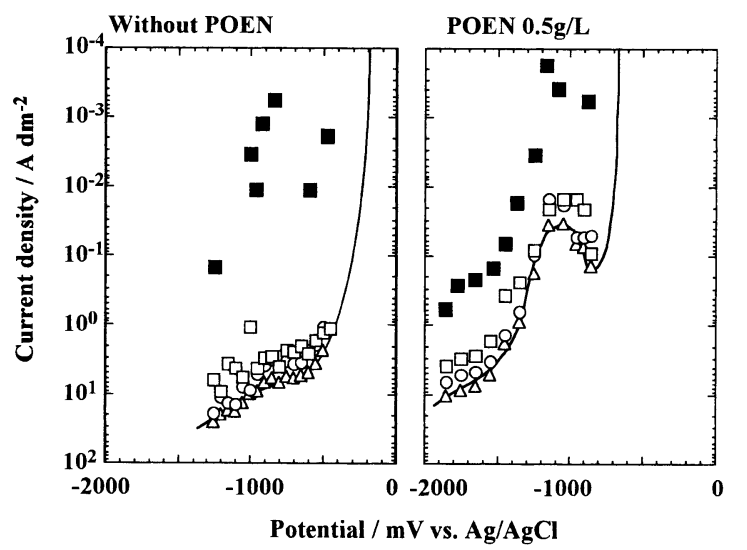

$\square$ isn $\square$ izn $O$ isub $\triangle$ inet

Fig. 5 Effect of addition of POEN on partial cathodic polarization of $\mathrm{Sn}-\mathrm{Zn}$ eutectic alloy electrode in sulfosuccinate bath $(\mathrm{pH} 4.5)$ at $25^{\circ} \mathrm{C}$
$\mathrm{mV}$ 付近にあり， $\mathrm{i}_{\mathrm{net}}$ の大部分を $\mathrm{i}_{\mathrm{Sn}}$ が占め， $\mathrm{i}_{\mathrm{Zn}}$ および $\mathrm{i}_{\mathrm{sub}}$ は 極めて小さい。すなわち，Sn析出のカソード電流効率は高 く，水素ガスの発生もほとんどない。 $\mathrm{pH}$ の上昇に伴い，析 出電位は卑にシフトし， $i_{\text {sub }}$ の増大に伴う $i_{\mathrm{Zn}}$ の増大が認め られた。

Table 1 に示した基本めっき浴 (pH 4.5) 中において，微小 $\mathrm{Sb}$ 電極を使用し作用極近傍の $\mathrm{pH}$ 変化を測定した結果を Fig. 7 に示す。共晶組成の皮膜が得られたカソード電流密 度 $3 \mathrm{~A} / \mathrm{dm}^{2}$ においては, 作用極近傍の $\mathrm{pH}$ 上昇が認められ， 作用極からの距離 $0.1 \mathrm{~mm}$ では pH 5.25 の值を示した。作用 極からの距離が $2 \mathrm{~mm}$ 以上においては, バルクの $\mathrm{pH}$ と等し い值を示した。Znの共析が認められなかったカソード電流 密度 $0.05 \mathrm{~A} / \mathrm{dm}^{2}$ においては, 電解に伴う作用極近傍の $\mathrm{pH}$ 上 昇が認められなかった。

以上の結果は, $\mathrm{pH}$ の上昇に伴いカソード表面への POEN の吸着性が増大し，これに伴うSn析出の分極が増大（Sn 析出の抑制）することにより，Znの共析が可能となること を示唆している。

\section{3 析出皮膜の結晶構造および融解特性}

Table 1 に示した基本浴から，カソード電流密度 $2 \mathrm{~A} / \mathrm{dm}^{2}$ において Cu素地上に作製した共晶組成を有する $\mathrm{Sn}-\mathrm{Zn}$ 合 金皮膜の，電析直後および熱処理後の X 線回折パターンを

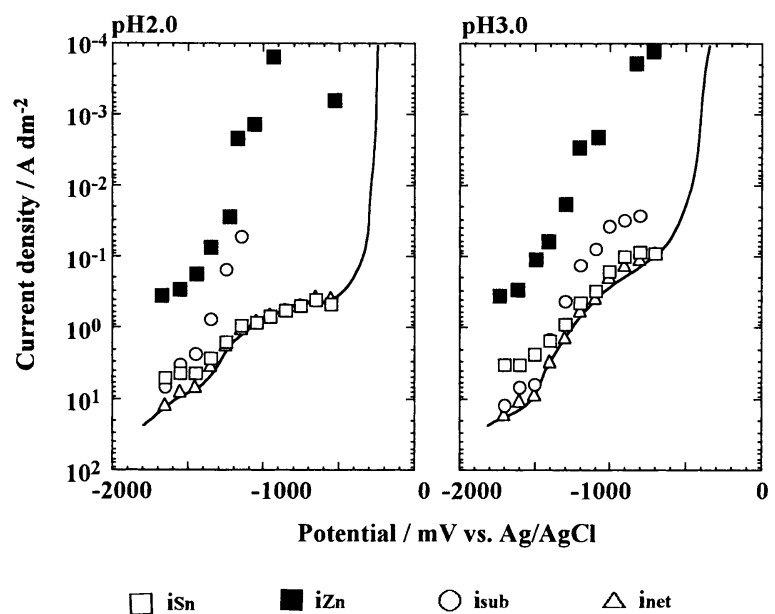

Fig. 6 Effect of $\mathrm{pH}$ on partial cathodic polarization of $\mathrm{Sn}-\mathrm{Zn}$ eutectic alloy electrode in sulfosuccinate bath with $0.5 \mathrm{~g} / \mathrm{L}$ POEN at $25^{\circ} \mathrm{C}$

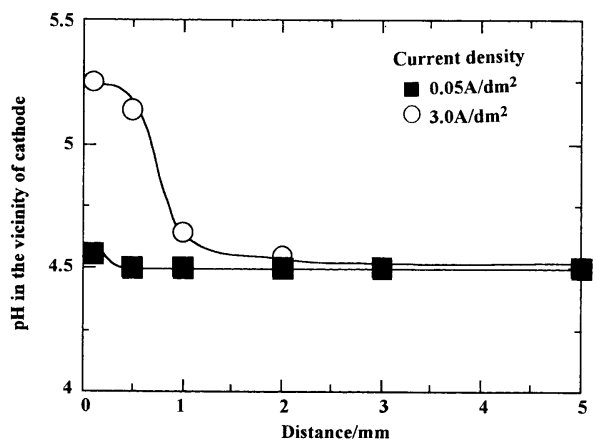

Fig. 7 Relation between pH in vicinity of cathode and cathodic current density 
Fig. 8 に示す。 $\mathrm{Cu}$ 素地上の電析直後の合金皮膜では, $\beta-\mathrm{Sn}$ およびZn の回折線の他に CuZn 金属間化合物の微弱な回折 線が認められた。CuZnの存在は, 合金皮膜中の $\mathrm{Zn}$ がCu素 地に拡散して $\mathrm{Cu}$ 素地と優先的に反応することを示唆して いる。 $250^{\circ} \mathrm{C}, 20 \mathrm{~min}$ のリフロー後の試料では, $\beta$-Sn および $\mathrm{Zn}$ の回折線の減少, $\mathrm{CuZn}$ の回折線の増大および $\mathrm{Cu}_{6} \mathrm{Sn}_{5}$, $\mathrm{Cu}_{3} \mathrm{Sn}$ の回折線の発現が認められた。 $\mathrm{Cu}$ 素地上の電析直後 の合金皮膜の深さ方向の元素分布をGDOESにより測定し た結果を Fig. 9 に示す。電析直後の合金皮膜においても $\mathrm{Cu}$ 素地表面へZnが拡散移動し, CuZn 層を形成していること が明らかとなった。一方, Fig.10に示すようにNiめっき素 地上の電析直後の合金皮膜では, $\beta$ - Sn, Zn および素地に由 来する回折線か認められた。 $180^{\circ} \mathrm{C}, 2 \mathrm{~h}$ の熱処理後において も, $\beta-\mathrm{Sn}, \mathrm{Zn}$ および素地に由来する回折線のみが認められ, $\mathrm{Cu}-\mathrm{Zn}$ および $\mathrm{Cu}-\mathrm{Sn}$ 金属間化合物の形成は認められなかっ た。したがって，ZnのCu素地側への拡散を防ぐためには Niめっきバリアが有効である。

皮膜単独（ステンレス鋼素地から合金皮膜を機械的には く離したもの）およびCu素地上の皮膜の DSC 曲線を Fig. 11 に示す。皮膜単独では, $\mathrm{Sn}-\mathrm{Zn}$ 共晶合金の融解温度である $198^{\circ} \mathrm{C}$ 付近に吸熱ピークが認められた。しかし, Cu素地上 の皮膜では, Sn の融点 $\left(232^{\circ} \mathrm{C}\right)$ に近い $223^{\circ} \mathrm{C}$ 付近に吸熱ピー クが移行した。この融点上昇は, Fig. 8 に示した $\mathrm{Cu}$ 素地上

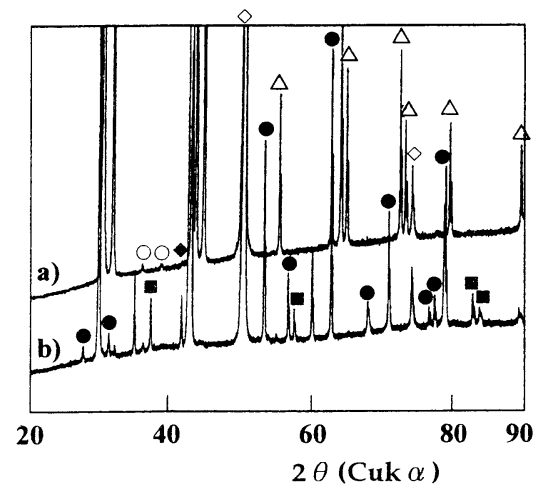
a) as plated
b) $250^{\circ} \mathrm{C} \quad 20 \mathrm{~min}$

$\bigcirc \mathrm{Zn} \triangle \mathrm{Sn} \diamond \mathrm{Cu} \bullet \mathrm{Cu}_{6} \mathrm{Sn}_{5}-\mathrm{Cu} 3 \mathrm{Sn} \bullet \mathrm{CuZn}$

Fig. 8 XRD patterns of $\mathrm{Sn}-\mathrm{Zn}$ eutectic alloy film on $\mathrm{Cu}$ substrate

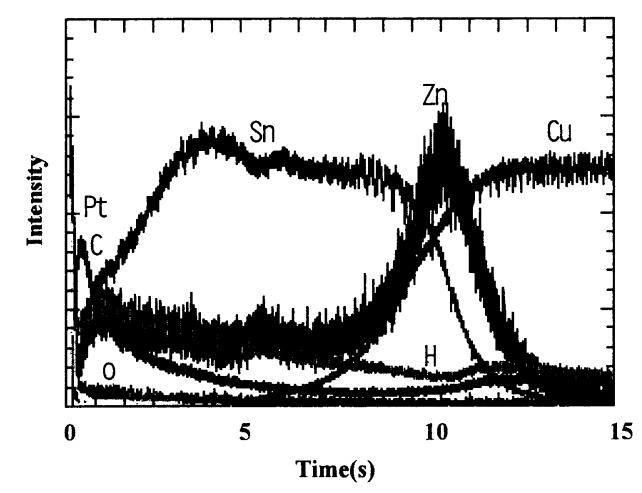

Fig. 9 GDOES depth profile of $\mathrm{Sn}-\mathrm{Zn}$ eutectic alloy film as plated on $\mathrm{Cu}$ substrate

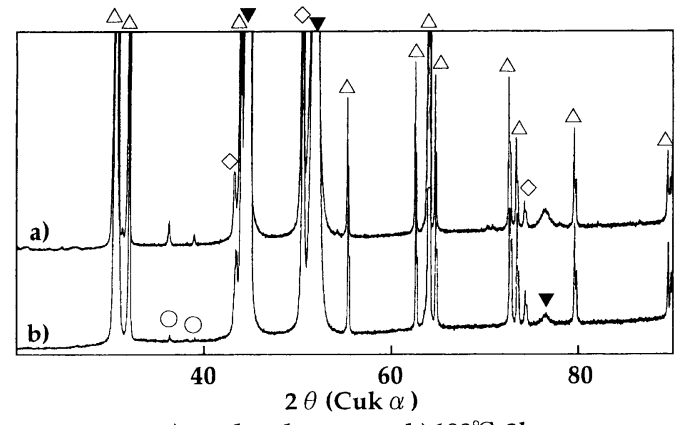

$\begin{array}{ll}\text { a) as plated } & \text { b) } 180^{\circ} \mathrm{C} 2 \mathrm{~h}\end{array}$

Fig. 10 XRD patterns of Sn-Zn eutectic alloy film on plated $\mathrm{Ni}$ film on Cu substrate

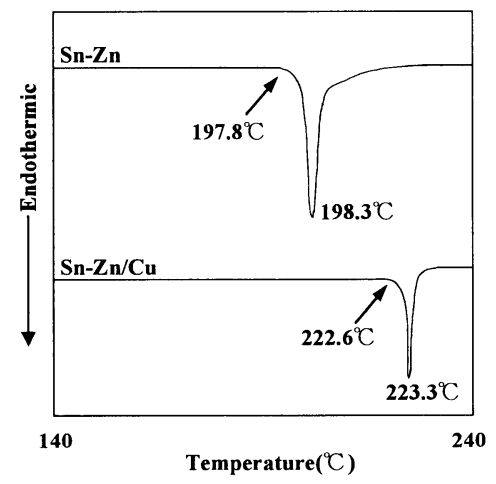

Fig. 11 DSC charts of Sn-Zn eutectic alloy film.

の合金皮膜の X線回折パターンからも明らかなように, DSC 昇温時に Sn-Zn 合金皮膜中の亜鉛が $\mathrm{Cu}$ 素地側に拡散 したことに起因している。ただし，本研究におけるDSC 昇 温速度は $2 \mathrm{~K} / \mathrm{min}$ であることから, 融点近い温度での保持 時間が長い。通常の実装においては，炉内の通過時間が短 いことから，合金皮膜中の $Z \mathrm{n}$ のほとんどが拡散移動する ようなことはないものと考えられる。

\section{4 ウイスカ}

$\mathrm{Cu}$ 素地上の共晶組成を有する $\mathrm{Sn}-\mathrm{Zn}$ 合金皮膜は，室温 で1年間放置後においてもウイスカおよび塊状隆起物の発 生は認められなかった。電析 $\mathrm{Sn}$ および $\mathrm{Sn}$ 基合金皮膜から のウイスカ発生要因については, 表面酸化説 ${ }^{16)}$, 吸蔵水素 説 ${ }^{17)}$, 内部応力説 ${ }^{18)}, \mathrm{Cu}$ 素材との間に形成される金属間化 合物説 ${ }^{19}$ 等が提唱されているが不明瞭な点が多い。しかし, 現在までにウイスカ発生に関して下記の事実が確証されて いる。

1) ウイスカは電析直後に発生するのではなく, 数日か ら数週間の誘導期間が存在する。特に，大きな圧縮応 力を有する光沢 $S n$ 皮膜では, ウイスカが短時間で発 生・成長する。

2) $\mathrm{Cu}$ 素材上の $\mathrm{Sn}$ および $\mathrm{Sn}-\mathrm{Cu}$ 合金皮膜からは，室温 における見かけ上静的条件下においてもウイスカが発 生・成長する。しかし， $\mathrm{Cu}$ 素材に $\mathrm{Ni}$ めっきを施すこ とにより, ウイスカの発生・成長が著しく抑制される。 特に，2)に関しては同一電析皮膜であっても，素材によ 
りウイスカ発生の有無があり, 電析皮膜自身にはその要因 が極めて希薄であることを示唆している。これらの事実か ら, ウイスカ発生の要因は素材との界面に形成・成長する 金属間化合物に起因している可能性が極めて高い。

本研究の $\mathrm{Cu}$ 素地上の $\mathrm{Sn}-\mathrm{Zn}$ 共晶合金皮膜においても, Fig. 8 およびFig. 9 に示したX 線回折パターンおよびGDOES による深さ方向の元素分布からも明らかなように, 電析直 後の皮膜において $\mathrm{Cu}$ 素地との界面に $\mathrm{CuZn}$ 層が存在し，応 力発生の要因である $\mathrm{Cu}-\mathrm{Sn}$ 金属間化合物の形成・成長を抑 制していることが示唆された。

\section{4. 結 論}

スルホコハク酸浴からの $\mathrm{Sn}-\mathrm{Zn}$ 合金の電析について，共 晶合金皮膜を得るための電析条件を確立するとともに，Zn の共析機構を電気化学的に検討した。また, 電析皮膜の結 晶構造, 融解特性およびウイスカ発生・抑制の要因につい て検討し，以下の結論を得た。

1) $\mathrm{POEN}$ を添加剤とする弱酸性のスルホコハク酸浴か ら, 0.5-3 A/ $\mathrm{dm}^{2}$ のカソード電流密度領域において, 浴 中の金属イオン濃度比にほぼ等しい共晶組成を有する 合金皮膜が得られた。カソード近傍の $\mathrm{pH}$ 上昇に伴い カソード表面への POEN の吸着性が増大し，これに伴 いSn 析出の分極が増大 (Sn 析出の抑制) することによ り Zn が共析する。

2) $\mathrm{Sn}-\mathrm{Zn}$ 合金の電析においては，Znの標準電極電位が $\mathrm{Sn}$ のそれに比べ卑であることから, $\mathrm{Sn}-\mathrm{Ag}, \mathrm{Sn}-\mathrm{Cu}$ およ び $\mathrm{Sn}-\mathrm{Bi}$ 合金の電析に共通の問題である, 合金金属イ オンのレドックス系からも浴の安定性に問題がない。 本浴は経時に伴う $\mathrm{Sn}^{4+}$ 化合物の沈殿形成は皆無であ り アノードや析出皮膜上への $\mathrm{Zn}$ の置換析出も当然 生じることなく，優れた作業性を有している。

3) 電析皮膜は $\beta$ - Sn と Zn の共晶構造であり, $\mathrm{Cu}$ 素地上 の皮膜には電析直後においても CuZn 層の形成が認め られた。CuZn層の形成に伴う, ウイスカ発生の要因 の 1 つである $\mathrm{Cu}-\mathrm{Sn}$ 金属間化合物の形成・成長の抑制 が示唆された。

4) 電析 $\mathrm{Sn}-\mathrm{Zn}$ 共晶合金皮膜は, 共晶温度である $198^{\circ} \mathrm{C}$ 付近で融解したが， $\mathrm{Cu}$ 素地上の皮膜は $223^{\circ} \mathrm{C}$ 付近で融 解した。この融点の上昇は, DSC 昇温時において皮膜 中の $\mathrm{Zn}$ が $\mathrm{Cu}$ 素地側に拡散移動したことに起因してい る。Znの拡散を防ぐにはNiめっきバリアが有効であ る。

(2002.6.17-受理)

\section{文献}

1) “鉛フリーはんだに関する調查研究成果報告書”, 日本電 子工業振興協会, 2000

2) 梁田 勇：“スズービスマス合金めっき”，第4回環境対応 実装技術フォーラムテキスト, p. 2-1-1, 1996
3）工藤富雄：“スズ-ビスマス合金めっき”，第 4 回環境対応 実装技術フォーラムテキスト, p. 2-2-1, 1996

4) S. Arai and T. Watanabe: "Electrodeposition of Sn-Ag Alloy with Non-Cyanide Bath", DENKI KAGAKU, Vol. 65, p.1097, 1997

5) T. Kondo, K. Obata, T. Takeuchi and S. Masaki: "Bright TinSilver Alloy Electrodeposition from an Organic Sulfonate Bath Containing Pyrophosphate, Iodide and Triethanolamine as Chelating Agents", Plating and Surface Finishing, Vol. 85, No. 2, p. 51,1998

6) 縄舟秀美, 池田一輝，北村浩司，水本省三，武内孝夫，青 木和博：“L-酒石酸錯体浴からのスズ-銀合金めっき”，表 面技術，Vol. 49, p. 759, 1998

7) 縄舟秀美, 芝 一博, 水本省三, 武内孝夫, 青木和博 : “メタンスルホン酸浴からのスズー銀共晶合金めっき”，表 面技術，Vol. 51, p. 1234, 2000

8) 縄舟秀美, 池田一輝, 芝 一博, 水本省三, 武内孝夫, 青 木和博: “メタンスルホン酸浴からのスズー銅合金めっき”, 表面技術，Vol. 50, p. 923, 1999

9）福田光修, 平川康一, 松本泰道: “鉛フリーはんだ用 $\mathrm{Sn}-\mathrm{Cu}$ 合金めっき”，表面技術，Vol. 50, p. 1125, 1999

10）須賀唯知, 菅沼克昭, 竹内 誠：“JIEP低温鉛フリーはん だプロジェクトの概要とアンケート調査結果”, 第 11 回マ イクロエレクトロニクスシンポジゥム論文集, p. 7,2001

11) 田中浩和, 中村 誠, 植田文崇, 吉原佐知雄, 白樫高史: “QCM法による鉛フリーはんだのイオンマイグレーション 過程に及ぼす要因解析”，エレクトロニクス実装学会誌, Vol. 3, p. 600, 2000

12）忠内仁弘, 小松 出, 立石浩史, 手島光一: “錫・覀鉛系 フローはんだ付け技術”，第 11 回マイクロエレクトロニク スシンポジウム論文集, p. 243, 2001

13) 北島雅之, 竹居成和, 庄野忠昭, 山崎一寿, 野口道子 : “Sn-Zn 系鉛フリーはんだ材料の開発”，第11回マイクロエ レクトロニクスシンポジゥム論文集，p. 247, 2001

14) 縄舟秀美, 池田一輝, 水本省三, 武内孝夫, 青木和博 : “スルホコハク酸錯体浴からのスズ-亜鉛合金めっき”，表 面技術, Vol. 48, p. 1007, 1997

15）東京都立衛生研究所：“内分泌かく乱物質（67物質）デー 夕集”, p. 59, 1998

16) J. Eshelby: "A Tentative Theory of Metallic Whisker Growth", Phys. Rev., Vol. 91, p. 755, 1953

17) N. Sabbagh, H. McQueen: "Tin Whiskers - Causes and Remedies_”, Metal Finishing, Vol. 73, No. 3, p. 27, 1975

18) S. Britton: "Spontaneous Growth of Whiskers on Tin Coatings -20Years of Observation_-, Trans. Inst. Metal Finishing, Vol. 52, p. 95, 1974

19) K. Tu: "Interdiffusion and Reaction in Bimetallic $\mathrm{Cu}-\mathrm{Sn}$ Thin Films”, Acta Metallurgica, Vol. 21, p. 347, 1973 